\title{
Potential Analysis of Rural and Urban Land and Building Taxes in Minahasa Regency
}

\author{
Erwin Momongan ${ }^{1}$, Itje Pangkey ${ }^{1}$, Jeane Langkai ${ }^{1}$ \\ Email: erwin20140719@gmail.com
}

${ }^{1}$ Master of State Administration Faculty, Manado State University, Indonesia

Received: March 10, 2021

Revised: April 12, 2021

Accepted: June 06, 2021

\begin{abstract}
The purpose of this study is to analyze the contribution of Rural and Urban Land and Building Tax (PBB-P2) to Minahasa Regency Regional Revenue, the determinant factor of PBB-P2 revenue which has the most tax objects/subjects but has not contributed to Minahasa Regency Locally-generated revenue (PAD) and Strategies in seeking PBB-P2 in Minahasa Regency to provide real contribution to local revenue. This research method includes a qualitative approach and a quantitative approach to the BPPRETDA case study method. SWOT-Quadrant Analysis. The results of quadrant 1 position score 0.29 external opportunities \& 0.12 internal strengths. Progressive action, the SO matrix is recommended by BPPRETDA to increase (NJOP \& tax rate $0.3 \%$ ), increase (officer education, facilities \& tax revenue sharing), and collect PBB-P2 data. Potential Determination of Rp.134,128,478,400,- (11\% Regional Revenue). It is necessary to determine the (Selling Value of Tax Object (NJOP) of land and buildings to be increased to near market prices with office work and field inspections and to support education, training for officers is needed to continue to be carried out in collaboration with the Ministry of Finance or independently by the Regional Government.
\end{abstract}

Keywords: Potential Tax, Regional Income, Land and Building Tax

\section{Introduction}

Indonesia's financial management includes the concept of decentralization, which means that the central government is obliged to allocate state financial budgets to be managed by local governments while seeking local revenue sources as a form of regional independence, but many regions are not yet independent (Firman, 2009; Pepinsky \& Wihardja, 2011; Nasution, 2017).

The Government of the Republic of Indonesia pays great attention to all regional governments, both at the provincial and district-city levels in the context of efforts to increase economic growth and community welfare as well as a government service approach. As the quote reads "Regional Governments have the authority to carry out government affairs according to the principle of autonomy and assistance duties with the principle of autonomy as widely as possible in accordance with the system of the Unitary State of the Republic of Indonesia" in Law Number 23 of 2014.

The tax revenue is obtained from levies made to all parties, both the community and the government itself. In addition, taxes are also used as a tool to influence the course of a country's economy through fiscal policy (Bird, 2008; Atkinson \& Stiglitz, 2015). Tax management can be interpreted as a series of processes starting from first collecting data on tax objects or subjects, secondly determining the tax payable and thirdly collecting taxes from taxpayers and finally monitoring their payments (Van Lelyveld \& Schilder, 2003; Haufler \& Wooton, 2006; Huseynov \& Klamm, 2012). 
One of the potential of the government or district / city is local taxes. "The types of taxes that are managed by districts/cities consist of: a). hotel tax, b). restaurant tax, c). entertainment tax, d). advertisement tax, e). street lighting tax, f). taxes on non-metallic minerals and rocks, g). parking tax, h). groundwater tax, i). wallet bird nest tax, j.) rural and urban land and building tax, and k). fees for the acquisition of land and building rights" (Law No. 28 of 2009).

(Rural and Urban Land and Building Tax) PBB-P2, hereinafter referred to as tax, is a tax on land and/or buildings that are owned, controlled, and/or utilized by individuals or entities. Earth is the surface of the earth which includes land and inland waters and seas in the Minahasa Regency area. Building is a technical construction that is permanently planted or attached to land and/or inland waters and/or sea" (Law Number 28 of 2009). So, everyone who owns or uses or spans the earth and or buildings, then that person already has the obligation to pay PBB$\mathrm{P} 2$.

This tax is imposed on land and or buildings. Land which has economic, political and social meaning causes people to tend to own it, while buildings have a unique special meaning, especially their fixed location, long-term use, having aspects of comfort and social strata and access to public facilities provided (Ahmad \& Krelove, 2000); Firman, 2004).

PBB-P2 collection is a series of data collection, determination, collection and reporting of PBB-P2. Minahasa Regency is a district formed in the territory of North Sulawesi Province in 1959 based on Law Number 29 of 1959 and is one of 15 regencies/cities in the North Sulawesi Province consisting of 25 sub-districts with 227 villages and 43 sub-districts as stated in the Information Report. Accountability of the Regional Head (LKPJ) of Minahasa Regency in 2018, (2019:2). The land area is $1029.82 \mathrm{~km} 2$, extending at $1^{\circ} 22^{\prime} 44^{\prime \prime}$ North Latitude/124³3'52"E.

In 2016 Realization of Regional Income Rp. 1.314.066.320.326,-, Realization of PBB-P2 Rp. $23,768,913,615$, - with a percentage of $0.29 \%$. In 2017 Realization of Regional Income Rp. 1,276,079,815,204,-, Realization of PBB-P2 Rp. 4,247,597,780,- with a percentage of $0.33 \%$. In 2018 Realization of Regional Income Rp. 1,267,974,996,960,-, Realization of PBB-P2 Rp. $4,303,427,444,-$ with a percentage of $0.34 \%$. In 2019 Realization of Regional Income Rp. 1,300,024,724,183,-, Realization of PBB-P2 Rp. 5,249,922,249, - with a percentage of $0.40 \%$. In 2020 Realization of Regional Income Rp. 1,242,280,017,828,-, Realization of PBB-P2 Rp. $4,686.662,433,-$ with a percentage of $0.38 \%$

The realization of PBB-P2 has not made a significant contribution to the structure of the Regional Revenue and Expenditure Budget (APBD) through regional income which in percentage only touched $0.35 \%$ of the annual average. This research was conducted with the aim of conducting an analysis related to the contribution of PBB-P2 to Minahasa Regency Regional Revenue. Determinant factors of PBB-P2 revenue which have the most tax objects/subjects but have not contributed to Minahasa Regency's PAD and Strategies in trying to make PBB-P2 in Minahasa Regency make a real contribution to regional income.

\section{Methods}

The research uses a qualitative approach with a case study method on strategic factors of potential PBB-P2 revenue in Minahasa Regency after that it is tested quantitatively on strategic factors that have been found to get the position of the implementation strategy that is relevant to current conditions according to Sugiyono (2010). This research was conducted at the Minahasa Regency Regional Tax and Retribution Management Agency, from March to May 2021. 
First, the qualitative approach becomes the research instrument is the researcher himself, so it is hoped that its validity is as described by Sugiyono (2010). Researchers as human instruments choose informants as data sources, determine research focus, collect data, assess data quality, interpret data and conclude on their findings. The data and information used is about the Management of Rural and Urban Land and Building Taxes in Minahasa Regency and its supports. In this study, it can be grouped into primary data and secondary data sourced from BPP-RETDA, BPKAD, Department of Public Works and Spatial Planning, BPS, BPK-RI, Dinas Perumaahn Rakyat with data collection techniques using active Participatory Observation, unstructured interviews, structured interviews and Documentation. Quantitative approach with questionnaires to the Camat, Lurah, Sub-District/Kelurahan and Taxpayers.

Data analysis using SWOT analysis technique. Rangkuti (2000) SWOT analysis is an analysis of the internal and external conditions of an organization in this case BPPRETDA which will then be used as the basis for designing strategies and work programs for BPPRETDA in the management of PBB-P2. Internal analysis includes an assessment of the factors of strength (Strength) and weakness (Weakness) while external analysis includes factors of opportunity (Opportunity) and challenges (Threaths). There are two kinds of approaches in SWOT analysis, namely: (1) Qualitative Approach to SWOT Matrix, and (2) Quantitative Approach to SWOT Diagram.

In testing the validity of the research data, it includes the credibility test (internal validity) from the truth value aspect in the form of triangulation, transferability (external validity) from the application aspect, the researcher tries to make a report by providing a detailed, clear, systematic, dependability (reliability) description from the consistency aspect with how to conduct an audit by a supervisor on research, and confirmability (objectivity) from the naturality aspect with a questionnaire to taxpayers, Sugiyono (2010)

\section{Results and Discussion}

PBB-P2 tax objects are 131,570 tax objects with 49,159 tax subjects, 320,554,582 m2, building area 2,908,035 m2, land NJOP (average) Rp. 14,035, the number of system buildings is 55,922 units, the average building NJOP is Rp. 641,794 , the average tariff is $0.12 \%$, and the NJOPTKP is Rp. 491.590 million.

The Minahasa Regency Government is still finding it difficult to separate from the Central Government regarding the revenue budget. Minahasa Regency's PAD is still very low in its contribution to Regional Revenue which only touches an average of $7.75 \%$, not in accordance with the dignity of regional autonomy.

The Minahasa Regency Government has 2 times written off receivables of Rp. 8,505,188,514, - while the amount of receivables as of December 31, 2020 is Rp. 12,278,572,013, -. The average addition of annual receivables is Rp. 1,754,081,716, - even in 2017 and 2019 the expired receivables were written off. But for years.

From the revenue side of PBB-P2 in 2020 it can be seen that it is Rp. 4,686,662,433, while the total regional tax revenue is Rp. 32,182,464,625, - then the percentage of PBB-P2 on Regional Tax is only $14 \%$.

Several Strategic Factors that Can be Used in the PBB-P2 Potential Analysis

These Internal Strategic Factors

Strengths (1) Local tax collection incentives; (2) Facilities and infrastructure; (3) intensification team; (4) PBB-P2 services; (5) Leadership, communication Cooperation of top, middle and low levels of PBB-2 management; (6) Tax rates; (7) Training on technical mastery of PBB-P2 management apparatus.

Copyright $@$ 2021, Journal of Asian Multicultural Research for Economy and Management Study, Under the license CC BY-SA 4.0 
Weaknesses (1) PBB-P2 management staff; (2) Place of payment for PBB-P2; (3) Tax Receivables; (4) Tax subject and tax object data; (5) Number of field officers (6) Socialization activities (7) Active billing is rarely carried out by BPP-RETDA officers; (8) Billing by force letter. never did; (9) Easy access to data and pear to pear.

\section{The PBB-P2 External Strategy}

Opportunities: (1) Land selling price (market price); (2) the land area has not been covered in the PBB-P2 object database; (3) Building area; (4) building value; (5) Infrastructure improvement; (6) Residential development; (7) Government policy on the composition of APBDes.

Threats: (1) Community situation; (2) Geographical conditions; (3) Taxpayer's address; (4) Consumptive nature; (5) awareness of paying taxes; (6) Locally-generated revenue (PAD) decreased due to low Rural and Urban Land and Building Tax (PBB-P2) revenue

From the strategic factors that have been found, the researcher combines the 4 elements of these strategic factors into four strategic options that will be used in the process of increasing the potential of PBB-P2 called the SWOT Matrix. Consists of four parts.

\section{Strategy Strengths-Opportunity (SO)}

(1) the determination of the NJOP (Selling Value of Tax Object) of land and buildings to be increased to close to the market price by means of office work and field inspections; (2) the tax rate is increased to $0.3 \%$ according to the law; (3) training education is added; (4) Building facilities and infrastructure are beautified, computers are added; (5) data collection for coverage of all Land And Buildings which are included in PBB-P2 object (6) the composition of tax revenue sharing is increased.

\section{Strategy Weaknesses-Opportunities (WO)}

(1) billing with forced letters is more often done; (2) increase the number of PBB-P2 ASN; (3) open payment cooperation with other private companies; (4) improvement of the data system so that data is more easily accessible by the Regent, BPN, sub-districts, villages, taxpayers and the public; (5) improvement of subject and object data system into synergy with field data; (6) socialization, celebrations, gifts are immediately intensified; (7) more frequent active billing; (8) increase regional capital expenditure.

\section{Strategy Strengths-Threats (ST)}

(1) increase public awareness of paying taxes; (2) involving the intensification team to inspire the community on the importance of PBB-P2 for the community and village and regional development; (3) PBB-P2 service in the sub-district or up to the village (pick up the ball); (4) incentive percentage is added.

\section{Strategy Weaknesses- Threats (WT)}

(1) provide a reduction in the amount of tax, installments for PBB-P2 payments (2) tax relaxation through $0 \%$ late fines (3) provide leeway for the payment of PBB-P2 (4) stimulus when the pbb-p2 is paid off receiving government program assistance.

The score of internal strategic factors (strengths and weaknesses) in the management of PBBP2 is 0.12 and the total score for external strategic factors (opportunities and threats) in the management of PBB-P2 is 0.29 . By combining the 2 values, the position of the SWOT analysis results is in quadrant 1, namely the management of PBB-P2 The Minahasa Regency Government has the opportunity to reach a score of 0.29 out of a total of 1 , which means that the environment/external starting from the tax obligation, social economy indicators,

Copyright (C) 2021, Journal of Asian Multicultural Research for Economy and Management Study, Under the license CC BY-SA 4.0 
development, etc. very supportive in efforts to increase Regional Revenue in the field of PBB$\mathrm{P} 2$. On the other hand, these advantages are in line with the internal quality of BPP-RETDA, several important things to be explored. Real affirmative action (progressive) is needed in the process. The strength it has is at a positive number 0.12 out of 1 , it is enough to use the strength of BPP-RETDA in terms of managing PBB-P2.

With the large number of tax objects, there is no guarantee that regional income in the PBBP2 sector will increase. From the existing calculations, it is known that the potential for Determination of PBB-P2 is Rp. $134,128,478,400$, - it can reach $11 \%$ contribution to Minahasa Regency Regional Revenue.

Internal Strategic Factors

\section{Local Tax Collection Incentives}

As a booster for the spirit of tax collectors and their very strong influence on PBB-P2 revenue, this weight is very large at 0.09 out of a total of 1 , while from the questionnaire respondents' point of view they stated a score of 0.27 with a strong internal strategic factor classification. With this high score, it provides an opportunity for the Minahasa Regency government to increase the amount of local tax collection incentives from 5\% to greater. With the increase in incentives for collecting local taxes, the positive implication is the enthusiasm of P2 PBB tax collectors, either by BPPRETDA itself or from officers in the village.

\section{Facilities and Infrastructure}

Auxiliary Media for PBB-P2 Management, this strategic factor is very important in supporting the processing of PBB-P2 because how is it possible that the management officer of PBB-P2 can work but there is no building or in the service there is no waiting room for taxpayers, there will be taxpayer dissatisfaction with the facilities provided by BPP-RETDA. From various sources of information, it is important to get that these infrastructures and facilities have quite an impact on increasing the potential of PBB 2, how about 0.06 for existing robots and 0.19 given by the questionnaire.

\section{Intensification Team}

The management of PBB P2 involves all elements of society in terms of seeking to increase their tax potential, the Minahasa Regency Government has formed a team for intensification and extensification of regional taxes and regional levies. The result score of the questionnaire questionnaire of 0.18 is included in the category of strong internal strategic factors.

\section{PBB-P2 Service}

In the system and procedures for managing PBB-P2, BPPRETDA is faster than DGT. This can be justified because in accordance with comparing the service processes for these two agencies, it can be justified that the era of BPPRETDA is faster than the DGT. Masengi (2018) states that "to achieve efficient public service management there is one factor that needs to be considered including "a fast way of working" which means choosing from several ways of working that are considered the same speed without reducing the value or desired goal of several alternatives. the method that is considered fast, it can be chosen which one is the fastest with the least risk". From the weight of the research results of 0.06 , it is included in the category of internal strategic factors which is quite strong, while the overall score is confirmed through questionnaires and questionnaires giving a score of 0.19 for internal strength.

\section{Leadership, Communication Top, Middle and Low Collaboration}

Seeing the PBB-P2 receipts in 2019 and 2020 there was a significant increase. This was because there were instructions from the Regent to BPPRETDA in order to increase P2 PBB revenues,

Copyright (C 2021, Journal of Asian Multicultural Research for Economy and Management Study, Under the license CC BY-SA 4.0 
with his capacity as the head of the Agency to pressure the Camat to follow up on the Regent's instructions and in stages the ranks of the Camats did the same thing to the villages and the results were quite promising where the UN revenue even in the pandemic era still touched the $100 \%$ figure. Looking at the existing weight of 0.09 , this figure is very strong in terms of its internal strategic factors and after being confirmed through the questionnaire, it can be seen that the number touches 0.28 and among the internal strategic factors, this strategic factor is the strongest.

\section{Tax Rate}

As a tax multiplier number that has been set by the local government of Minahasa Regency of $0.1 \%$ and $0.2 \%$, some stakeholders conclude that the value of the understanding power of the existing weight value is 0.09 after being clarified by the questionnaire respondents that they agree on this tax rate. The value achieved is 0.28 and is the strongest internal strategic factor at number 2 .

\section{Training on Technical Mastery of PBB-P2 Management Apparatus}

Further perfecting the PBB-P2 process is in line with Masengi (2018) that "the existence of education and training facilities can provide the first goal of increasing knowledge, skills, skills and attitudes in carrying out professional duties based on personality and ethics". Judging with the conditions on the ground, most of the state civil apparatus managing PBB-P2 have been provided with a certificate of assessor for PBB-P2. Seeing this weight at 0.06 with a score of 0.19 implies that this strategic factor is quite strong from the internal side of strategic factors.

\section{PBB-P2 management staff}

PBB-P2 administrative staff at BPPRETDA is considered to be still less proportional in number compared to the number of tax objects of 7309 tax objects / state civil apparatus, not including the division of labor for the management of BPHTB which in 2020 is 1,599 tax objects. Seeing this condition is very risky for ASN staff, there will be a lot of jobs that are neglected or not good and ineffective. Both respondents and BPPRETDA agree that this strategic factor weakens the process of exploring the potential for PBB-P2, which can be seen from the weakness weight of 0.09 and the score of this item at -0.25 , this figure is the most negative of the many weakness factors.

\section{Place of Payment PBB-P2}

The two choices of PBB-P2 payment places are considered sufficient as a standard for managing PBB-P2. The first consideration is that the two payment options make it easier for the process of recording PBB-P2 payment transactions. P2, Why is it said that because the limited choice of place of payment can interfere with the smoothness of the PBB-P2 payment, it can be seen from the results of the questionnaire that was carried out that respondents gave a negative value of 0.17 and included in the category of weak internal strategic factors . Expectations from taxpayers that the place for payment of PBB-P2 will be expanded further considering current developments. People paying taxes are getting better at increasing PBB-P2 potential.

\section{Tax Receivable}

Every year PBB-P2 gives a negative contribution in the form of receivables of $\mathrm{Rp}$. $1,754,081,716$ for regional finance, of course this is a bad incident for financial management, especially PBB P2 which needs to find the best solution to suppress the receivables. From a weight of 0.09 and a negative score of 0.24 it can be said that tax receivables have an impact on the weakness of the internal strategic factors of BPPRETDA. 


\section{Tax Subject and Tax Object Data}

Looking at the condition of the existing database based on conditions in the field, it can be found that a lot of data system data is less valid, a weight of 0.06 and a negative score of 0.18 indicates that this tax subject and object data weakens internal strategic factors.

\section{Number of Field Officers}

The village officer is not enough as a support system for the implementation of P2 PBB collection and collection at the village village level. This is quite influential, seeing that there are only officers from the guard or head of the environment who are not proportional to the number of objects and tax subjects they run. Indeed, from the weight given only 0.03 and and a negative score of 0.08 this number is no less hampering the collection of PBB P2 but it clearly has an effect.

\section{Socialization}

The socialization activity is one part of the effort to transfer information held by BPPRETDA to all levels of society or taxpayers, whether it is carried out directly by the region or through intermediaries through the village government, with limited budgets. In addition, through this socialization activity there will be sharing of information which will later become the basis for evaluating the management of PBB P2 and the final goal is to increase revenue from PBB P2. However, the situation did not go well due to budgetary problems so that this socialization activity was rarely carried out on a massive scale to all taxpayers in the Minahasa district. Looking at the weight of 0.03 and a negative score of 0.08 , it can be said that this internal strategic factor weakens the process of increasing PBB P2.

\section{Active Billing is Rarely Done by BPP-RETDA Officers}

Efforts to pick up the ball in the active billing of PBB P2 are highly recommended to be done, but this rarely happens due to various kinds of obstacles, this condition is quite an obstacle in the process of collecting PBB P2. With a weight of 0.06 and a negative score of 0.18 , it is enough to give a bad influence on internal strategic factors.

\section{Billing by Force Letter}

In connection with the points above, billing with forced letters has never been carried out, some of the reasons are quite basic when this is not done because this is in contact with repressive law enforcement where in collection with forced letters this will lead to the confiscation of assets as part of compensation for PBB-P2 payments. Another reason is that billing with a forced letter will consume a lot of energy by both the officer and the taxpayer himself and there is the involvement of law enforcement elements including it. Every long process must be passed by each party. The weight of 0.06 with a negative score of 0.18 is sufficient to illustrate that this internal strategic factor is weakening.

\section{Easy Access to Data and Pear to Pear}

Easy access to data by the Minahasa Regent, Camat, Hukum Tua/Lurah, taxpayers and public/external organizations. The pear to pear data relationship with the BPN, the Population and Civil Registration Service, BPN, SULUT GO BANK has not been fully achieved considering that with security considerations, the PBB P2 system is still offline, the impact is not fulfilled by outsiders. The guidance of the five point zero digital era does require that data must be easily accessed by certain parties. The weight of 0.03 and a negative score of 0.08 is enough to have an impact on the weakness of internal strategic factors.

Strategis Eksternal PBB-P2 


\section{Selling Price of Land (Market Price)}

This clearly shows that the land njop data does not match the current situation. Even since it was transferred from the Directorate General of Taxes, the Ministry of Finance of the Republic of Indonesia in 2014, many kelurahan have not been adjusted to the NJOP, contrary to article 6 letter (2) of Regional Regulation Number 1 of 2013 where the amount of NJOP is determined once every 3 (three) years and is excluded. for certain tax objects can be determined every year in accordance with the development of the region. One of the reasons for adjusting the NJOP every 3 (three) years or less is due to regional/national inflation factors. It is known that the length of the coastline is 3 nautical miles or $5.56 \mathrm{~km}$ or $5560 \mathrm{~m}$. Assuming the width of the beach is 200 meters with a NJOP of 60 times (the value of the NJOP system is Rp. 3,500 m2), the potential for determining the object of a coastal tax is Rp. 446,000 .000,-..(0,2\% X Rp. $3,500,-$ X 60 X 200 X 5560 ). Land area has not been covered in the rural and urban land and building tax object database. The land area in the rural and urban land and building tax object database is $320.55 \mathrm{~km} 2$ while the land area is $555.4 \mathrm{~km} 2$ excluding forest area with a ratio of $60 \%$ of the total area of Minahasa Regency

Building Area

With many buildings that have not been subject to PBB-P2, of course, this provides great potential for PBB-P2 revenues. This can be explained with a very large weighted number of 0.09 with a score of 0.26 reflecting how big the opportunities offered by external parties are for increasing the potential for land and building taxes in rural and urban areas in Minahasa Regency.

\section{Building Value}

both the NJOP of land and the NJOP of buildings still have a large gap compared to the real conditions listed in the PBB-P2 database. The researcher concludes that NJOP is an internal strategic strength as a potential booster for PBB-P2. Simple Building Value max. 2 floors is Rp. 5,900,000/m2 (Perbup. Number 541 of 2020)

\section{Infrastructure Upgrade}

To increase fixed assets, local governments allocate funds in the form of capital expenditures in the APBD. This capital expenditure allocation is based on regional needs for facilities and infrastructure, both for the smooth implementation of government tasks and for public facilities. Usually, the procurement of fixed assets is held annually by the regional government, in accordance with budget priorities and public services that have a long-term financial impact.

\section{Residential Development}

The growth of settlements in several locations/districts experienced an upward trend, this illustrates how well Minahasa Regency's growth is going. With the development of existing settlements, of course, this will also result in an increase in the potential of PBB P2, the number of new settlements of course in terms of the selling value of land and the determination of taxes from buildings will increase. The weight of 0.06 and a score of 0.18 is sufficient to provide opportunities for increasing the potential of PBB-P2 in terms of external factors.

Government Policy for the Composition of APBDES.

The PBB-P2 process involves the government and the village/kelurahan community from incentives to $10 \%$ local tax revenue sharing in the APBDes, not to mention the policy from the central government by allocating funds for all villages which almost touches one billion rupiah, there are even several villages with an area and the large population exceeds one billion rupiah. 
Given the cyclical effect, there is quite a chance to increase the potential of PBB P2, which is evident from the weight of 0.03 and a score of 0.08 from external factors.

\section{Community Situation}

covid 19 has an "antagonist" impact on the acceptance of PBB-P2. The weight of 0.09 with a negative score of 0.28 clearly illustrates that the community situation is a threat to the increase in PBB P2.

\section{Geographical Conditions}

The condition of some hilly areas provides a little challenge for PBB P2 management officers to collect or collect. With a weight of 0.06 and a score of 0.15 enough to provide a threat in increasing the potential of PBB-P2.

Taxpayer Address

Many taxpayers domiciled outside the village/kelurahan make it difficult to collect the bill, where some live outside the Minahasa Regency, outside the province of North Sulawesi and even abroad. Of course, if the billing is done face-to-face, the determination will not match the operational costs. Referring to the weight value of 0.06 and a negative score of 0.19 , it means that the address of this taxpayer is a serious threat to the potential increase in land and building taxes.

\section{Consumptive Nature}

The personal character of the taxpayer which is generalized to consumptive causes the PBB$\mathrm{P} 2$ payment option to become a non-priority. The respondent agreed with this factor by giving a score of -0.24 for the external serious threat factor.

Awareness of Paying Taxes

This tax is also used as a source of subsidies to the poor. This is not understood by the public, causing taxes to be a heavy obligation to implement. A negative score of 0.25 means how big the threat of this external factor.

\section{PAD Decreased Due to Low PBB-P2 Revenue}

It is clear that with the lack of Rural and Urban Land and Building Tax (PBB-P2), of course, the pea is automatically corrected for low and the effect is that the financial independence of regional autonomy does not work, this is evidenced by a negative score of 0.18 from external threat factors.

\section{Conclusion}

The analysis of internal strength factors shows that the management of PBB-P2 with the amount of the 5\% local tax levy incentive is sufficient with the hope that it can be improved, the facilities and infrastructure have been supported, the intensification team is working quite good, PBB-P2 service is fast, Communication Leadership, Cooperation, Top/Midle/Low are good, $0.1-0.2 \%$ tax rate is temporary enough and education training on technical mastery of PBB-P2 management apparatus is qualified. Weakness factor analysis shows that PBB-P2 management staff is lacking, the place for payment of PBB-P2 is limited, there is an increase in Tax Receivables of more than Rp.1 m/year, data on tax subjects and tax objects are not appropriate, the number of field officers is lacking, Socialization activities, Gebyar, Prizes, Direct less/never, Active PBB-P2 collection is rarely done, Billing by forced letter as the implementation of Minahasa Regent Regulation Number 28 of 2013 as part of reward and punishment has never been carried out and Ease of Access to Data which is still difficult. Analysis of opportunity factors in the form of high market price, large land area, large 
building area, high market value of buildings, good infrastructure improvement, good settlement development, government policy from the composition of APBDes and there is a $10 \%$ regional tax revenue sharing fund. Threat factor analysis shows that the situation of the community is not good where in 2020 the whole world including Minahasa Regency is experiencing a covid 19 pandemic, hilly/mountainous geographical conditions slightly interfere with the smoothness of billing, addresses of taxpayers outside the village/kelurahan tax object make it difficult to collect, the nature of high consumption and awareness of paying low taxes and most significantly decreasing PAD due to low PBB-P2 revenues.

\section{References}

Ahmad, E., \& Krelove, R. (2000). Tax assignments: options for Indonesia. In seminar on "Agenda for Sequencing Decentralization in Indonesia.

Atkinson, A. B., \& Stiglitz, J. E. (2015). Lectures on Public Economics: Updated Edition. Princeton University Press.

Bird, R. M. (2008). Tax challenges facing developing countries. Institute for International Business Working Paper, (9).

Firman, T. (2004). Major issues in Indonesia's urban land development. Land Use Policy, 21(4), 347-355.

Firman, T. (2009). Decentralization reform and local-government proliferation in Indonesia: Towards a fragmentation of regional development. In Review of Urban \& Regional Development Studies: Journal of the Applied Regional Science Conference (Vol. 21, No. 2-3, pp. 143-157). Melbourne, Australia: Blackwell Publishing Asia.

Haufler, A., \& Wooton, I. (2006). The effects of regional tax and subsidy coordination on foreign direct investment. European Economic Review, 50(2), 285-305.

Huseynov, F., \& Klamm, B. K. (2012). Tax avoidance, tax management and corporate social responsibility. Journal of Corporate Finance, 18(4), 804-827.

Masengi, E. E. (2018). Pengantar Manajemen Pelayanan Publik (Cetakan II). Malang: Wineka Media.

Nasution, A. (2017). The government decentralization program in Indonesia. In Central and local government relations in Asia. Edward Elgar Publishing.

Pepinsky, T. B., \& Wihardja, M. M. (2011). Decentralization and economic performance in Indonesia. Journal of East Asian Studies, 11(3), 337-371.

Rangkuti, F. (2000). Analisis SWOT Teknik Membedah Kasus Bisnis”. Jakarta: PT Gramedia Pustaka Utama.

Sugiyono, (2010). Metode Penelitian Kuantitatif Kualitatif dan R\&D. Jakarta: CV. Alfabeta.

Van Lelyveld, I., \& Schilder, A. (2003). Risk in financial conglomerates: Management and supervision. Brookings-Wharton Papers on Financial Services, 2003(1), 195-224. 